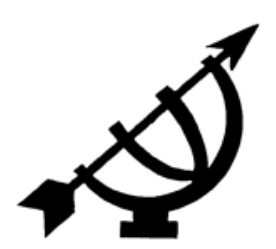

\title{
Belief and legal philosophy: a conceptual framework for Christian scholarship in undergraduate legal education
}

\author{
S. de Freitas \\ Faculty of Law \\ University of the Free State \\ BLOEMFONTEIN \\ Email: defreitas.RD@ufs.ac.za
}

\begin{abstract}
Belief and legal philosophy: a conceptual framework for Christian scholarship in undergraduate legal education

Legal education in South Africa has arrived at a discursive juncture that demands clarity on what the "purpose" of legal education should be. Debate on the purpose of legal education, more specifically for the Christian law student, becomes especially important in a society dominated by positivism, materialism and pragmatism. With specific reference to the undergraduate Christian law student, this article firstly explains that the purpose of legal education should include the nurturing of the student's belief - a belief encompassing his/her foundational perspective(s) on reality. Secondly, in order to achieve the proper nurturing and development of the Christian law student's belief, the importance of the teaching of legal philosophy is explained. In this regard, proposals are postulated pertaining to specific means by which such nurturing and development of the undergraduate Christian law student's foundational belief can be attained.
\end{abstract}

\section{Opsomming}

Geloof en regsfilosofie: 'n begripsmatige raamwerk vir Christelike vakkundigheid in voorgraadse regsopleiding

Regsopleiding in Suid-Afrika het by 'n diskursiewe tydstip gekom wat duidelikheid vereis oor wat die "doel" van regsopleiding behoort te wees. Debat oor die doel van regsopleiding, meer spesifiek vir die Christen-regstudent, word veral belangrik in 'n nuwe samelewing wat oorheers word deur positivisme, 
materialisme en pragmatisme. Met spesifieke verwysing na die voorgraadse Christen-regstudent, maak hierdie artikel dit eerstens duidelik dat die doel van regsopleiding die koestering van die student se geloof behoort in te sluit - geloof wat sy/haar grondliggende perspektief(we) oor die werklikheid omvat. Tweedens, ten einde die behoorlike koestering en ontwikkeling van die Christen-regstudent se geloof moontlik te maak, word die belangrikheid van die onderrig van regsfilosofie duidelik gemaak. In hierdie verband word voorstelle wat spesifiek verband hou met maniere waarop sodanige koestering en ontwikkeling van die voorgraadse Christen-regstudent se grondliggende geloof bereik kan word, gepostuleer.

\section{Introduction}

These are challenging times for higher education in South Africa, where critical discussion on the purpose of higher education is especially relevant to legal education. 1 There is an overwhelming affiliation towards three essential requirements of the practitioner, namely a basic knowledge of the law and where to find it; an understanding of the relationship of law to the social and economic environment in which it operates; and the ability to handle facts and to apply abstract concepts to those facts (cf. Barnett, 1995:108). What have also been observed are two vital aspects that debate on legal education views as its purpose; these are the teaching of the knowledge of where to look for the answer, and the cultivation of the ability to define the problem in order to seek the answer. 2 These approaches imply the expectation that legal education needs to assist in the attainment of such requirements, and consequently this is where the contemporary emphasis is placed in such education. Although important, these popular insights limit legal education to an overwhelmingly skills-based and pragmatic approach in which the positive law (or the "written" law of the day) forms the main point of reference, irrespective of the nature of its content. This overwhelmingly positivistic tendency is further fueled by the dictates and attractions of market forces and the popular perception of the law as

1 Included in such discussion are issues related to theory versus practice; new teaching and assessment methods; transformation in academia; the prioritisation of the natural sciences over other sectors of scholarship; pretertiary education as preparation for tertiary education; and the responsibilities of scholarship towards civic engagement (such as socio-economic development).

2 This is an observation by Martin (1995:45) regarding the position in America. However, the same can be said of the South African context. 
"solo-science". 3 In addition, contemporary liberal and pluralist society generally views religion as a private affair, and this is clearly witnessed within the halls of legal education in South Africa. 4 As a result the Christian law graduate enters the legal profession with a mind that might be well versed in "the law" (irrespective of what it may be), but bearing the risk of a legal mind far removed from its Christian foundations. All of this culminates in a negation of the foundational "belief" aspect of the Christian law student. The consequences are especially of concern, bearing in mind that brain development occurs in the late teens and early twenties, during which the frontal lobes and sub-cortical areas of the brain mature. These areas are associated respectively with abstract thought and with memory, attention and emotional control. Therefore students are, according to Bohlin (2005:102-103), at a particularly impressionable stage in their lives.

Consequently, this article firstly explains that the purpose of legal education should include the nurturing and development of the undergraduate Christian law student's belief dimension, which encompasses his/her foundational perspective(s) on reality. This includes the unveiling of the author's (SdF) own experiences in academia as a result of which it became clear that there is a void in terms of the integration of the Christian belief in the teaching of the law in South Africa, this especially when a substantial number of students are Christian. An analysis also indicates the importance of addressing the "deeper" issues related to legal education such as what should be regarded as good in life, which consequently leads to the need to address the concept of belief or foundational worldview in the education of the undergraduate Christian law student. In this regard, a proposed and universal meaning is ascribed to belief and applied to the Christian context. Secondly, in order to remedy the situation

3 Berman (1983:vii) observes that today people think of law primarily as the mass of legislative, administrative and judicial rules, procedures, and techniques applied in a given country. In contrast to this, one needs to take note of the Blackstonian approach in which natural law, divine law, the law of nations, English common law, local customary law, Roman law, ecclesiastical law, the law merchant, statutory law, and equity were intertwined with one another. In this, Berman (1983) is in support of the omnipresence of the law - the multiplicity of inextricable attachments the law has with the various sciences.

4 In fact, this is a result of a more general "anti-religious" sentiment in contemporary liberal democracies. For an apt argument confirming this (for the South African context as well) although pertaining specifically to the American context, see Carter (1993). 
described in the first part of this article, the importance of the teaching of legal philosophy is conceptually analysed and argued for, and more specifically, proposals are made pertaining to ways in which the teaching of legal philosophy at undergraduate level can be made not only more effective, but also more balanced, objective, and inclusive in its approach. This also has advantages for nonChristian law students.

It is important to note, however, that although the educative task in matters of belief is the responsibility of many sectors within society, for example the family, the school and the church, this article looks specifically at the educative task of the law faculty as an entity within higher education which also carries the civic responsibility of nurturing the belief aspect of the Christian law student. This does not imply an emphasis on the Christian law student to the exclusion of other students holding non-Christian beliefs. This article concentrates on Christian law students (at undergraduate level) precisely because of the over-emphasis of positivism, indulgence in materialism and the privatisation of religion $\mathbf{5}$ (as stated earlier) by contemporary society, including legal education, in South Africa and in many other liberal and pluralist states. To give effect to plurality, one also has to represent this a plurality, and in this regard Stuntz (2003:1708) succinctly states:

Bringing Christianity to bear on legal theory, as one of many perspectives in this age that exalts diversity, would be a good way to make legal theory for our pluralist society more pluralist. That might in turn allow our law to better represent the society it serves.

This observation is most applicable for the South African context, in which Christianity is substantially reflected.

\section{Belief and the educative task}

\subsection{Background}

Lecturing Introduction to legal philosophy to undergraduate final year law students produces valuable insights. Providing students with an abstract and ideology laden section of the law, brings about a certain optimism and curiosity that connects with their innermost

5 Religion is understood here in the traditional sense, for example, the mainstream traditional religions such as Christianity, Judaism and Islam. 
being. Students learn to understand the different shades of right and wrong, and learn about values and the origins of values. They realise that it is acceptable to be affiliated with a specific foundational belief when it comes to distinguishing between right and wrong - a belief that is not necessarily anchored in the lecturer, the faculty and/or the university. These students tend to play open cards when dealing with legal philosophically-inclined themes such as the interpretation of human rights, the weight of natural law (as opposed to the contemporary over-emphasis on positivism), the relationship between the law, morality and religion, the myth of neutrality, and the meanings and purposes of justice. Students also eagerly participate in and consider "ultimate" topics, which are sometimes accompanied by an internal conflict arising from what the student believes to be right or wrong, and what he/she is taught to be right or wrong in law school. In two recent class surveys (spanning a period of two consecutive years) conducted with the final year students in legal philosophy, 78\% commented (anonymously) that the Christian God is their axiomatic point of departure in distinguishing right from wrong. However, whether South African faculties of law accommodate a Christian context in legal education is strongly doubted. 6 This is being confirmed by, among others (and as mentioned before), commercial and material interests, a society which is sceptical of moral absolutes, Western society's emphasis on religious neutrality, the privatisation of religion, and a predominant emphasis on pragmatic and utilitarian goals in higher education.

Henderson's $(2003: 48,51)$ observation therefore makes sense regarding the many who leave law school disillusioned, perceiving the law as a value-neutral instrument and lawyers as persons who wield that instrument without regard to its impact on society. According to Henderson (2003:49), criticisms of legal education demonstrate that today's law students perceive legal education as alienating them from their values and ideals. What is witnessed in the above is surely contrary to the view that education should enhance and develop the student's personal values, interests and evaluations of what counts as good in life (Valenkamp \& Van der Walt, 2006:9; also see Higgs, 1991:165). Hauerwas (2007) rightly states that any knowledge worth having cannot help but shape who we are and accordingly our understanding of the world. Hauerwas therefore prefers referring to "moral formation" instead of "education" (Hauer-

6 Implied is the expectation of accommodating Christian education due to the prevalence of Christianity in South Africa. 
was, 2007:46). In this regard, Maclntyre states (quoted in Hauerwas, 2007:131):

Insofar as education has a moral import, it is not in and through the teaching of morality or values or religion or anything else as a separate and additional set of subjects; it is rather that there is a moral import in the whole structure of education, in everything that we teach, and that morality is not primarily about constraints upon how we pursue the various goals which we pursue, it is primarily about the nature of these goals themselves. 7

Bearing this in mind, education should include the enhancement and nurturing of the foundational belief aspect of the student, including the Christian law student. Morality, personal values, and that which counts as good in life are all inextricably connected to one's foundational belief system. What must then be understood by a foundational belief?

There are many interpretations of what should be understood regarding belief from a foundational angle. However, for the purposes of this article, belief refers to a loyalty to something or other as divine (divine means having the status of not depending on anything else; Clouser, 1991:21-22), and therefore, this divinity acts as the source from which all presuppositions in determining the individual's worldview emanate (Hiebert \& Hiebert, s.a.:14). 8 Belief in this context therefore has a foundational and pretheoretical (pre-scientific) connotation, and plays an important role in hypothesising on ultimate questions of human existence "not explaining the basic forces of the universe but understanding why there is a universe, not how our bodies operate but why they do, not how they enhance the range of choices arrayed before us but what choices we should make" (cf. Carter, 1998:497).

According to the Christian belief, the divine is God who created the universe and who does not form part of the universe nor is the universe part of God. Also, God created within the world an intelligible revelation of his relations to the universe, especially his relations to humans. In the words of Clouser (1991:43-44): "This body of teaching is the authoritative guide for all knowledge of God and the

7 Similarly Canavan (1977:45-46) states that: “... probably all legal questions have a moral dimension and involve moral issues".

8 For further explanation on this view of religion, see Clouser (1991:1-48). 
most important truths about humans. It includes the teaching of the core belief that only God is divine ..." Irrespective of the denominational affiliations of the Christian, the fact remains that his/her views on aspects and activities in reality will be influenced (or have the potential to be influenced) by the said core belief (to whatever degree). Therefore the law, as an important aspect and activity in reality, as well as the Christian religion, forms an inescapable part of the domain of foundational belief. In the spectrum of options of what should be right and wrong [the normative aspect presented by the law (and therefore legal education)], the Christian law student would (should) revert to the Christian foundational belief in trying to come to a solution regarding jurisprudential issues. In this regard, the Christian would refer, for example, to the Bible, commentaries on the Bible, teachings (written and spoken) of a specific denomination or church and so forth, to further clarify what his/her belief views as right or wrong. Therefore, belief in this regard refers to God (and his revelation) as part of the Christian student's foundational belief. This has implications for legal education and the legal profession. Understanding the belief aspect, and more specifically that of Christianity, one understands Stuntz's view that Christianity is a theory of everything, and everything includes the law. Stuntz (2003:1721) adds:

And Christianity is different from other theories of everything, particularly the non-theistic theories that dominate in universities today. Among other things, Christianity holds that 'good' and 'bad' find their definition not in men's and women's choices but in God's character.

Cognisance needs to be taken of the fact that not everyone believes: that same-sex marriages are right; morality and the law are separate; the foetus is not human; religion and the law are separate; the aim of the law is merely the betterment of society (without any further moral or religious aim); the law is aimed at pragmatic ends; freedom of expression qualifies trade in adult pornography; rehabilitation is superior to punishment in penological theorising; and in the unlimited validity of euthanasia. We all have views that are nurtured and informed by foundational beliefs, and which are not necessarily in agreement regarding the above issues. If these views are not properly addressed and nurtured, there could be adverse consequences for the student's intellectual, religious, and psychological well-being (including the conscience).

Consequently, the proceeding section of this article deals with the importance of legal philosophy in assisting the nurturing and deve- 
lopment of the Christian law student's foundational belief system, and provides specific proposals on how to effectively apply legal philosophy (and legal education in general). This also implies the value of legal philosophy for non-Christian law students.

\section{Proposals for the teaching of legal philosophy}

\subsection{Legal philosophy}

Cotterrell (2000:179) observes that legal philosophy has a moderately secure place in the undergraduate law curriculum in the United Kingdom, and adds that this is the situation after much controversy and many local skirmishes in university law departments. In this regard, Cotterrell (2000:179) comments that "[i]f this is so, it is because it is thought to offer something important that other law school courses cannot or do not offer". One might say that this understanding reflects the friction that existed in the United Kingdom between legal education in the empirical and pragmatic sense on the one hand, and legal education from a theoretical, more critical and philosophical angle, on the other. Some years ago, Barnett (1995:125) presented a very credible observation pertaining to the dissemination of legal philosophy in the United Kingdom, Canada and Australia, which confirmed that legal philosophy (albeit in its many guises) retains its force as an academic enterprise enjoying a central role in legal education. Barnett (1995:109; cf. also Penner et al., 2005:5) states that the relevance of legal philosophy for practice rests in the fact that it provides a critically challenging, reflective and morally evaluative perspective from which to appraise the increasingly positivistic realm of law. In studies done abroad on the relevance of legal philosophy, it has clearly been shown that the majority view is that legal philosophy provides intellectual diversity, has professional relevance, gives a broader perspective and understanding of law as an important social activity, and is an appropriate culmination of the academic study of law (Barnett, 1995:107). In the words of Kenealy (1950:103-104):

We are a learned profession as well as a practical one. We have a responsibility in thought as well as in conduct. The legal system of every nation is profoundly affected by the philosophy which dominates the leaders of its legal profession. Justice cannot be administered in a vacuum, without regard to a fundamental philosophy of life, of law, and of government. I confess to little patience with the so-called 'bread and butter' lawyer who cannot see the place of philosophy in the law. It is 
philosophy which shapes the law ... It is not a question of keeping philosophy out of the law; that cannot be done.

Within a subject such as legal philosophy, ideological expressions can naturally thrive due to the nature of legal philosophy as conducive to such expressions, because of their concentration on the metaphysical, epistemological and ethical dimensions of the law. Also, the popular views of legal philosophy as the study of general theoretical questions about the nature of laws and legal systems, the relationship of law to justice as well as morality (Freeman, 1994:4), and the study of the law's sources and purposes (Manie Triphathi, 1975:6) confirm the affinity of legal philosophy to the belief aspect. This implicates the inclusion of Christian (and other) jurisprudential knowledge. In South Africa there is a clear threat to the philosophical aspect of legal education (for reasons already explained), not to mention the scarcity of understanding part of the teaching of legal philosophy as the dissemination and nurturing of foundational beliefs, and even more so pertaining to Christian law students. In South Africa, legal philosophy is generally relegated to a semester or year subject (which is normally positioned in the latter half of the LL.B. course) and no more. After having surveyed the LL.B. course outline of eleven prominent South African law faculties, it became clear that nearly all teach legal philosophy for no more than two semesters. In a recent study of the subjects presented in the LL.B. curriculum, Kaburisa (2007) observes that legal philosophy ranks as secondary to no fewer than 26 other legal subjects. How, specifically, should the teaching of legal philosophy be structured in order to give effect to the foundational belief aspect of the Christian law student at undergraduate level?

\subsection{Proposals}

\subsubsection{Early teaching of legal philosophy}

One must ask whether basic concepts and theories related to legal philosophy are taught earlier on in the LL.B. curriculum. It is essential that the Christian law student become familiar with foundational philosophical concepts and ideas early on in his/her undergraduate career, not only to establish a sturdy intellectual platform for the rest of the LL.B. curriculum, but also to anchor in the student the understanding that law and "foundational beliefs" are not separate from one another. It is in fact already in the first year of legal studies that the student is confronted and influenced by a barrage of subjects and ideas that could provide the impression that the law and Christianity (religion) are separate from one another (not to 
mention the potential risk of having a lecturer who may be opposed intentionally or unintentionally, to the Christian or religious aspect). In the same manner, the non-Christian law student can also be erroneously taught that religion does not form part of the law, which could consequently cultivate an unnecessary antireligious sentiment which is not reflective of a pluralist and tolerant approach. In addition, the non-Christian law student will also, by being exposed to foundational legal philosophical concepts and postulations (including the belief aspect), gain in the knowledge of the law as encompassing more of reality than originally thought of. Some teachers of legal philosophy might be critical in the sense that they might view the teaching of legal philosophy to a first year student as potentially overburdening the student. However, this should not be the case, as legal philosophy could be taught in a more simplistic yet enriching format, where introductory passages on the meaning of (legal) philosophy, the nature of law, the meaning of justice, the relevance of ideology, the neutrality principle, insights into natural law and positivism could be creatively structured to captivate the student. In this regard, sources used also need to be representative of the various mainstream ideologies or religions, with special emphasis on the role and contributions of the Christian religion to the development of jurisprudence. From a historical view, Christianity contributed much to the development of jurisprudential, political and ethical theory. Part of this teaching must include an effort to unleash the critical and inquisitive mind of the student, the latter to be taught that the law comes from certain contexts and is formed by various views and life perspectives - in other words emanating from and formed by various foundational beliefs. At present, the early teaching of legal philosophy is watered down to form part of the Introduction to the law module and therefore is not effectively (regarding creative methods), objectively (regarding main themes referred to below), or inclusively (regarding the inclusion of a wider spectrum of sources) being taught to first years (or to the more senior students) in the LL.B. curriculum in South Africa.

Cognisance must be taken of the fact that law students must have a sufficient knowledge of law in order to appreciate its theoretical (philosophical) dimensions, while on the other hand, they should be open-minded enough to accept and adapt to the particular skills and modes of legal philosophical thought and not to have a built-up resistance to the latter (Barnett, 1995:103). Therefore, the concentration of the dissemination of legal philosophy in the initial stages of the LL.B. curriculum must be sensitive to the risk of over-burdening the student before the student gains a reasonable knowledge of the 
positive law, while simultaneously cultivating in the student an affinity to legal philosophy, an affinity to an open mind according to the dictates of a desired belief. Once this is effectively attained the student ought to be prepared for a more in-depth approach to the teaching of legal philosophy - closer to, or in the final year of study. Having been exposed to an earlier introductory course on legal philosophy would surely prepare the student (including the Christian law student) for a more in-depth approach to legal philosophy.

\subsubsection{The pretheoretical aspect}

The Christian law student needs to be introduced to the fact that each individual is inextricably connected to a foundational belief the proverbial worldview. In other words, worldview as understood as a foundational belief (such as a specific religion, for example) in the sense that it is a premise taken from reality, which dominates man's understanding/experiencing of reality, including the law. A pretheoretical point of departure (also referred to as a pre-scientific point of departure) is that which surpasses mere facts, that which surpasses what is limited to detection and confirmation by the senses, as well as that which surpasses assumptions surrounding the core belief or assumption. Belief understood as a loyalty to something or other as divine, is nothing other than a pretheoretical point of departure, albeit a foundational one. In understanding the pretheoretical character of norms, the Christian (and non-Christian) law student will realise that law and belief (or religion) are inseparable. The pretheoretical character of norms can be taught in many creative ways.

Legal philosophy implies the study of general theoretical questions about the nature of laws and legal systems (Freeman, 1994:4) - that specialised field of the law that critically investigates the nature, truth and ideological aspect of the law and/or its content. Legal philosophy plays an important role, not only in the development of a critical mind that can assimilate, structure and systematise facts leading to a rational and convincing argument, but also in the context of experiencing the foundations and nature of the law. In turn, these issues are based on pretheoretical foundational belief systems. These pretheoretical foundations are reflected in, for example, the $A B C$ of (legal) philosophy, namely metaphysics, epistemology and ethics. It is in terms of these three basic philosophical pillars that first contact should be made regarding the belief aspect and consequently the introduction of a particular belief as the underlying or axiomatic pretheoretical base of various jurisprudential issues. 
The role that religion, such as the Christian religion, plays in this regard is neglected in contemporary legal education.

The assistance of the pretheoretical (including foundational belief) is required in answering the difficult jurisprudential questions related to, for example, same-sex marriages, the status of the unborn, whether freedom of expression qualifies trade in adult pornography, or whether morality and the law are separate from one another. By emphasising the pretheoretical aspect, the Christian student will realise that the law and the Christian faith are inseparable. In fact, an emphasis on the pretheoretical aspect in legal education would be most valuable to all law students, Christians and non-Christians alike, in that the student would be made aware that the content of the law has a deeper, more underlying and foundational meaning and origin than the law understood as merely facts to memorise and apply. Also, the freedom to decide one's view on the said contentious matters is of value to all students.

In addition, all students need to be carefully and clearly educated in matters such as the distinction between facts and concepts, the meaning of theory, the complex nature of the law due to its pretheoretical and conceptual nature, and the reasons why judges differ on ethical issues (in the context of the pretheoretical aspect). All these matters, on deeper reflection, result in a clear insight as to the importance of the pretheoretical jurisprudential context, and consequently lay the foundation to an understanding of the foundational belief aspect itself. It is also here that the student can be taught the meaning of belief in the context of "a loyalty to something as divine". This not only opens the door to the inclusion of many types of foundational beliefs, but also provides those who are antireligious with the opportunity to better understand and accept the fairness of also allowing traditional religions in the law curriculum. In fact, for the non-Christian law student to realise that he/she has some or other pretheoretical foundation in coming to conclusions on jurisprudential issues is in itself enriching.

\subsubsection{Neutrality and its jurisprudential implications}

There has been much written on and confirming Western society's emphasis on ideological and religious neutrality when it comes to debate within the public sphere (there have also been as many critical arguments in this regard), the latter perceived to be in coexistence with the privatisation of religion. This view has infiltrated higher education as well, and has influenced, among other things, a proper and balanced dissemination of the law. The Christian law 
student needs to be made aware of the myth of neutrality in the law. Thiessen (2007:25) observes that prominent liberal theorists such as Rawls and Macedo would ask students and teachers within a common school to adopt a kind of epistemological neutrality. This entailed the bracketing of their ultimate commitments, hereby limiting themselves to a public reasonableness, consequently being in support of a so-called "neutral public rationality". However, a loyalty to the latter forces teachers and students to leave aside their most cherished beliefs in public discussions. Surely it is not necessary to explain the myth of neutrality when it comes to teaching. It would be more of a priority for purposes of this article to unveil the negative view levelled at critics of neutrality in that such criticism of neutrality paves the way for totalitarianism in the classroom (Kleinig, 1982:102). It seems that any criticism levelled at the neutrality of teaching signifies hostility as opposed to the socalled friendliness of the secular status quo, and also that this approach is rather unfortunate as well as theoretically unfounded. What is also experienced is that students initially become confused when first taught about the myths of objectivity and neutrality in the law (in fact in all the sciences or aspects of reality). However, the students soon realise the value of being able to notice the myth of neutrality, which in turn provides them with more comfort in the exercise and proclamation of their own views - the student will soon come to realise that it is, after all, not so bad to take sides!

Cotterrell (2000:184) touches on this by stating that the fact that there are no objectively right answers in legal philosophy may seem obvious to those who teach it, but can be deeply disturbing for students: "until, that is, they realise that it can be illuminating to see the favoured answers given in professional legal thought as limited". This provides Christian law students with the prospect of realising that understanding the nature of law is a quest open to them using their own developing experience; "not a matter of seemingly finished knowledge, like a House of Lords decision that cannot be appealed". This understanding provides a constructive challenge declaring that there are a plurality of perspectives on law, and that any teaching suggesting only a single perspective to be available is false and dangerous (Cotterrell, 2000:184), therefore also being of value to the non-Christian law student. In this regard, the non-Christian law student, by being properly taught regarding neutrality, can not only learn from this a sensitivity towards those fellow students who are, for example, from a Christian background, but can also come to the realisation that they themselves are anything but neutral. The end 
result of this is a levelling of the playing-field, where stigmatisation will be limited.

\subsubsection{Inclusion of Christian sources}

It is ironic that the contemporary popularity of pluralism, which in fact should effectively accommodate various foundational beliefs, seems to have become indicative of "a new expression of the melting-pot ideal", where persons from a wide variety of races and cultures are, according to Marsden, "welcomed into the university, but only on the condition that they think more or less alike" (Glenn, 2005:46). In fact, pluralism entails the exercise of tolerance regarding cultural and ideological expressions.

The presence of strongly held differences of belief on campuses should be dealt with by enforcement of rules of civility, not by intolerance toward and exclusion of a whole class of viewpoints. (Marsden, 1994:432.)

This also means that, more specifically, the teaching of the law should strive towards including a fair amount of material that is reflective also of Christian perspectives, especially for the South African context. For example, the module on legal philosophy should not ignore the contributions by the Church Fathers and the Reformation to the law, more specifically to themes on constitutionalism, human rights, equity and justice. It is a fact that in many faculties of law, students are introduced to classical contributions such as those of Plato and Aristotle, but what goes by unnoticed (whether intentionally or not) is that there are alternatives in embarking on a study in legal philosophy, either from Ancient Athens, or from Adam and Eve, either from creationism (from whatever Christian view) or from evolutionism (from whatever secularist view). Also, students are being taught erroneously in many instances, for example that John Locke is the father of human rights or that the Enlightenment was the cradle of social contractarian thought; and important insights on constitutional theory that arose from the minds of the Reformers such as Martin Luther, John Calvin, Heinrich Bullinger and Johannes Althusius are absent from the teaching. Being one-dimensional (especially to an overwhelmingly theistic audience) could have dire consequences for the student's perception of the religious foundations of the law, and the integration of these foundations with reality. Need it be said that the inclusion of Christian sources also has the potential of enriching non-Christian minds, in the same manner that Christian minds can learn certain insights 
from secular jurisprudence. In fact, many legal, political and moral values derive from religious teachings.

\subsubsection{Objectivity and inclusivity}

The question needs to be posed as to whether there is a truly objective and inclusive approach to the content (main themes) of legal philosophy, and whether the Christian student is properly introduced to the subject by first being taught the importance of such a subject before the real content is tackled. Legal philosophy is a course that could easily be abused (intentionally or unintentionally) by a lecturer, since biased opinions on fundamental jurisprudential questions could be interpreted by students as the truth. Cotterrell (2000:181) emphasises the risks involved in the dissemination of legal philosophy due to the breadth and inclusiveness of the subject - "it (legal philosophy) is a complex intellectual patchwork", the proverbial Pandora's box. Cotterrell (2000:181) observes that lecturers in legal philosophy often add their own personally prioritised themes to the legal philosophy module, themes that have originated from a "personal selection from a box full of ideas". From a South African context of legal education, one is truly concerned as to whether legal philosophy is disseminated in an objective and balanced manner (regarding the main philosophic themes), not to even mention the accommodation of those students who are Christian regarding Christian views on such main philosophical themes.

It is possible to attain a satisfactory level of objectivity and inclusivity in the undergraduate teaching of legal philosophy, irrespective of who might be in the audience, and irrespective of the ideological preferences of the lecturer. In this regard, and more specifically related to the substantive content of the module, themes dealing with positive law, natural law, neutrality, the meaning of law, objectivity, belief, philosophy, worldview, justice and the meanings of many other relevant and foundational concepts need to be dealt with, including Christian perspectives regarding such concepts. It is not only the Christian law student who may benefit from this approach, but also those non-Christian law students who are in many instances, and unfortunately so, being exposed to a very limited spectrum of legal philosophy. This is without even commenting on the limited scope awarded to the teaching of legal philosophy in comparison to other legal subjects, when looking at the LL.B. curriculum in general (as referred to earlier on).

It is also important to note that if philosophical sources from humanistic, liberal and non-Christian contexts can be used to address 
certain jurisprudential issues, then an effort can also be made to include Christian jurisprudential contributions. What makes secular sources superior to religious sources, since both share the concept of foundational belief? Not only does the law have a substantial Biblical background, but the depth and richness of legal philosophical works by, for example, St. Augustine, Thomas Aquinas and modern-day Christian philosophers have the potential of providing any student with important insights into legal issues and the relationship between the law and the rest of reality.

\subsubsection{Electives, programmes and existing subjects}

Faculties of Law should consider the inclusion of legal modules which are aimed at a specific foundational belief (or religion) - in this regard, the Christian faith. This would naturally depend on the percentage of representation of Christian law students at a given university. The introduction of electives in this regard is linked to the importance of teaching the essentials of legal philosophy in the first year (as discussed above), in that this will have influenced and prepared the Christian student regarding the importance of such an elective once he/she reaches the third or fourth year of legal studies. Such an elective will then have a more intense approach to the subject of legal philosophy with a substantial Christian dimension, also including other ideological perspectives which can be enriching both to the Christian and non-Christian law student. Although the availability of the necessary expertise, especially from a Christian point of view, might pose challenges, one must realise that there are many universities that have a substantial student and scholarly representation of the Christian faith, and law faculties should do a proper study in order to determine the demand in this regard. There can also be programmes which do not formally form part of the LL.B. course. A good example of this is the recent establishment of the Christian Legal Scholarship Programme for Southern Africa by the Christian Lawyers Association (CLA) (an affiliate of Advocates International, the international organisation of Christian lawyers). The CLA recognises that balanced Christian input from the legal profession is imperative for nation building and the alleviating of suffering in South Africa. Among its other ministries, the organisation seeks to engage law students in Christian and ethical thinking as an important step in empowering them to fulfil their calling in whatever sphere of the legal arena they find themselves once they complete their training. The said programme is a teaching course for highly motivated and committed law students. It is presented by foreign and local legal experts who lecture, from a Christian point of view, 
on topics related to the foundational aspects pertaining to the law, the interplay between worldview and the law, legal philosophy and application, the legal profession, as well as freedom of religion and the South African Constitution. The CLA presents this programme in collaboration with the University of the Free State. Another proposal would be to have Christian legal scholars visit and teach Christian law students at the various law faculties in South Africa.

Academics as well as members of the various churches and civil society should provide initiatives to address and apply the above proposals, of which the Christian Scholarship Programme is a good example. Individual initiatives might find the surrounding environment threatening and it is therefore necessary to establish networks where collectivities or structures are established in order to take Christian representation in legal education further. Steps are also to be taken by the said structures regarding credible evaluations in order to determine the needs of Christian law students at South African institutions of higher education. Higher education should formulate clear policies regarding the protection of foundational beliefs. 9 This will not necessarily be an easy process, and the context of one university might differ from the context of another. Nevertheless, efforts will need to be made to improve the situation.

The application of legal philosophy within various other legal subjects (some will naturally be more prone than others to philosophical connotetions) would also be an important step towards integrating and accommodating the relationship between belief and the law, also within a Christian perspective. Here one could especially emphasise subjects such as legal history, human rights, constitutional law, constitutional interpretation, criminal law, and criminology. These subjects have a strong moral element, which in turn are

9 In this regard, policies followed by certain institutions in addressing the student's values and interests are inspiring: one example being the American Association of Law Schools (AALS), which states that "Teachers should nurture and protect intellectual freedom for their students" (emphasis - SdF; Curtis, 2006:461-462). There is also the National Education Association (NEA) in America, which has specific standards by which all teachers' conduct may be monitored and judged. Among other things these standards state that: "The educator, believing in the worth and dignity of each human being (emphasis - SdF), recognizes the supreme importance of the pursuit of truth" (emphasis - SdF; Curtis, 2006:473). Consequently, these observations emphasise the need for addressing the student's affiliations to aspects related to belief (be it religion, philosophical opinion and/or worldview). 
encapsulated and determined by "belief". Stuntz (2003:1711), for example, states that:

Professors encourage law school students to analyze law from a variety of perspectives and points of view, but religious views are oddly absent. A student in criminal law, for instance, is unlikely to question modern criminological theory from the standpoint of sin and redemption. If a student [did so], many professors would not know how to react. There would likely be an awkward silence, followed by a polite change of subject. 10

\subsubsection{Natural law}

The overriding emphasis on substantially positivistic-inclined legal subjects, and the close to non-existent accommodation of knowledge on natural law in the LL.B. curriculum, is most disappointing. This reminds one of the old lawyer's joke stated and commented upon by Carter (1990:481):

If you don't have the law on your side, argue the facts; if you don't have the facts on your side, argue justice. Well, the scientistic approach to moral argument, and, by extension, to constitutional argument, is like that, too. Justice - the endproduct, if you will, of liberal theory - is treated as a secondbest (or perhaps third-best) subject of argument. Only fanatics make a lot of noise about morality; the smart, reflective liberal, however, makes an empirical case.

Natural law theory plays an important role in limiting the over-indulgence in positivism, and also in emphasising the importance of justice, its moral and Christian connotations and other insights related to such a concept. According to Hervada (2006:176), juridical science is often imbued with positivism, reduced to a positive science, such that the criteria of natural law play no role or at most a secondary role. A subject such as legal philosophy can be extended to accommodate themes on natural law which are most relevant to

Rushdoony (1995:140-141) similarly states that criminal law is based upon moral principle, adding that no society can teach morality without religion, as well as the fact that, as a matter of history, criminal and civil law derived from Christian teaching. In no manner does this insinuate that a lecturer in, for example, criminal law, should be expected to have specialised theological expertise. However, this is mentioned to emphasise that the law can have another dimension to it, and that legal education needs to be made aware of this. What the solutions should be, although discussed in other sections of this article (albeit not exhaustively), will differ from place to place and person to person. 
any Christian (and non-Christian) legal mind. In commenting upon Berkeley's Jurisprudence and Social Policy programme, Messinger and Selznick (1985-1986:695) state the importance of philosophy (and history) to legal scholarship in the context of cultivating a concern for fundamental values, which in turn deepens the commitment to justice as a governing ideal. Natural law theory has an integral role to play in this regard, especially when taking the values and principles of our South African Constitution into consideration. Natural law is ideally suited to the teaching of cardinal (justice, wisdom, courage, and temperance) and theological (faith, hope, charity) virtues that will make the necessary correction and proper grounding for character education in a pluralistic society that is principled towards religion (cf. Benson, 2008:133). In this regard the Christian and non-Christian law student will be taught that Christianity also shares much with other beliefs pertaining to jurisprudential perspectives. A proper teaching of natural law will explain to the Christian student Christianity's contributions to the law in general, hereby also informing him/her as to the interplay between belief, religion and the law. In this regard, Budziszewski (2006:8-9) states:

A natural law theory is an explanation of the relations among goods, virtues, formal norms, and everyday moral rules ... Natural law theories also explore such things as how we know the natural law, how our knowledge of it is clarified or obscured, and how its authority is rooted in God ... Although the various natural law theories disagree about technical points, they all agree that the foundational principles of morality are right for everyone, that by the ordinary exercise of human reason, they are known to everyone, that they closely parallel the contents of the Decalogue, and that their authority is rooted ultimately in God.

In fact, further research on the importance of natural law for the LL.B. curriculum would be a most welcome initiative for the South African context. It is unlikely that a separate and compulsory module on natural law will find space in the currently loaded LL.B. curriculum.11 However, broadening or intensifying the prospects of such a topic within electives or within a subject such as legal philosophy itself, will do much to remedy the situation.

11 Hervada (2006:175-176) provides a valid argument as to why "natural law" should be a unique and autonomous module. 


\section{Conclusion}

In the contemporary debate on the role of the university in legal education, an overwhelming emphasis is placed on training and educating the student from a practical and positivistic point of view. This has implications for Christian law students at undergraduate level, who run the risk of being influenced by jurisprudential views that may come into confrontation with their foundational belief. Consequently, a conceptual framework is postulated which could remedy (or improve) this situation. In this regard it is argued that legal philosophy can be effectively utilised to convincingly argue for the accommodation and cultivation of the law student's Christian convictions. When it comes to the teaching of legal philosophy, the risk of ideological bias is high. It is therefore hoped that the proposals provided in this investigation will assist in preventing an unbalanced and exclusive approach to the teaching of such a subject. More specifically, it is postulated that legal philosophy needs to be introduced early on in the LL.B. curriculum, include substantial teaching on epistemological and pretheoretical jurisprudential aspects, accommodate proper explanations regarding the concept of neutrality and its jurisprudential implications, include traditionally religious sources in a substatial way, to have a satisfactory element of objectivity and inclusiveness, be further developed by additional electives or programmes, and place more emphasis on the natural law aspect. The practical application of the said proposals, however, would require a concerted effort by the relevant Christian expertise and other potential role players to meet and further discuss the implementation and implications resulting from this article's findings (which should not be viewed as exhaustive). Associations in higher education need to be established and saddled with a specific mandate towards furthering the goal of the nurturing and development of the undergraduate law student's foundational belief system.

All of this would surely assist towards developing Mill's view that the proper business of a university is not to tell us what we ought to believe, but to provide us with information and to help us to form our own beliefs in a manner worthy of intelligent beings who seek for truth (Marsden, 1994:413). This is even more urgent and relevant when considering that there is a Charter for Religious Rights and Freedoms soon to be finalised for the South African community, stating among other things that: "Every person has the right on a 
voluntary basis to receive and provide religious education, training and instruction ...". 12

\section{List of references}

BARNETT, H. 1995. The province of jurisprudence determined - again! Legal studies, 1(15):88-127.

BENSON, I.T. 2008. Do "values" mean anything at all? Implications for law, education and society. Journal for juridical science, 33(1):117-136.

BERMAN, H.J. 1983. Law and revolution: the formation of the Western legal tradition. Cambridge: Harvard University Press.

BOHLIN, K.E. 2005. Character education at the university: a worthy purpose. (In Arthur, J., ed. Citizenship and higher education. London: Routledge. p. 96-116.)

BUDZISZEWSKI, J. 2006. Natural law for lawyers. Module for the Blackstone Legal Fellowship presented by the Alliance Defense Fund in the USA.

CANAVAN, F. 1977. Simple-minded separationism. The human life review, 3(4):36-46.

CARTER, S.L. 1990. Scientific liberalism, scientistic law. Oregon law review, 69(3):471-494.

CARTER, S.L. 1993. The culture of disbelief: how American law and politics trivialize religious devotion. New York: Basic Books.

CARTER, S.L. 1998. The constitution and the religious university. De Paul law review, 47:479-498.

CLOUSER, R.A. 1991. The myth of religious neutrality. Notre Dame: University of Notre Dame Press.

COTTERRELL, R. 2000. Pandora's box: jurisprudence in legal education. International journal of the legal profession, 3(7):179-187.

CURTIS, D.M. 2006. Everything I wanted to know about teaching law school I learned from being a kindergarten teacher: ethics in the law school classroom. BYU education and law journal, 2(2):455-498.

FREEMAN, M.D.A. 1994. Lloyd's introduction to jurisprudence. London: Sweet \& Maxwell.

GLENN, C.L. 2005. Universities of character? (In Arthur, J., ed. Citizenship and higher education. London: Routledge. p. 33-50.)

HAUERWAS, S. 2007. The state of the university. Malden: Blackwell.

HENDERSON, B.R. 2003. Asking the lost question: what is the purpose of law school? Journal of legal education, 53(1):48-79.

12 Article 8, Draft Charter on Religious Rights and Freedoms, (document as amended on 29 May 2008). Here the word religious could be interpreted as having a strictly theological connotation in the sense of excluding other sciences such as the law. However, and preferably, it can also refer to the fact that religious education includes theological aspects within the teaching of sciences beyond that of pure theology. In fact, I have submitted a proposal accepted for discussion by the working group of this charter, proposing that reference needs to be made in the charter to the accommodation of religious rights and freedoms in institutions of higher education. 
HERVADA, J. 2006. Critical introduction to natural law. Montreal: Wilson \& Lafleur Ltée.

HIEBERT, A.L. \& HIEBERT, D. Antiseptic education: the myth of irreligiosity. http://www.iclnet.org/pub/facdialogue/17/hiebert Date of access: 1 Oct. 2008.

HIGGS, P. 1991. The nature and mission of a university: a fundamental response - the evolution of the university in Europe and in the United States. South African journal of higher education, 2(5):164-168.

KABURISA, J.B. 2007. Structure of legal education in South Africa. http://www.aals.org/2000international/english/southafrica2.htm. Date of access: 10 Mar. 2008.

KENEALY, W.J. 1950. The majesty of the law. Loyola law review, 2(5):101-115.

KLEINIG, J. 1982. Philosophical issues in education. New York: St. Martin's Press.

MANIE TRIPHATHI, B.N. 1975. An introduction to jurisprudence and legal theory. 5th ed. Allahbad: Asia Press.

MARSDEN, G.M. 1994. The soul of the American university: from protestant establishment to established nonbelief. Oxford: Oxford University Press.

MARTIN, F. 1995. The integration of legal skills into the curriculum of the undergraduate law degree: the Queensland university of technology perspective. Journal of professional legal education, 1(13):45-62.

MESSINGER, L. \& SELZNICK, P. 1985-1986. Enlarging legal education: Berkeley's jurisprudence and social policy program. Nova law journal, 2(10):691-704.

PENNER, J., SCHIFF, D. \& NOBLES, R. 2005. Approaches to jurisprudence, legal theory, and the philosophy of law. (In Penner, J., Schiff, D. \& Nobles, R., eds. Introduction to jurisprudence and legal theory: commentary and materials. Oxford: Oxford University Press. p. 3-34.)

RUSHDOONY, R.J. 1995. Politics of guilt and pity. Vallecito: Ross House.

STUNTZ, W.J. 2003. Book review: Christian legal theory. Harvard law review, 111:1707-1749.

THIESSEN, E. 2007. A liberal case for educational pluralism. The Newman rambler, 1(9):22-29.

VALENKAMP, M. \& VAN DER WALT, J.L. 2006. "Quality of life" as a basic "principle" in/for the scientific disciplines, including education, with special reference to the spiritual dimension of life. Bloemfontein: Vereniging vir Christelike Hoër Onderwys. (Unpublished paper presented at a Seminar on Quality of Life, 27 Jul. 2006.)

\section{Key concepts:}

Christian education

legal education

legal philosophy

university 


\section{Kernbegrippe:}

Christelike onderwys

regsfilosofie

regsopleiding

universiteit 
